
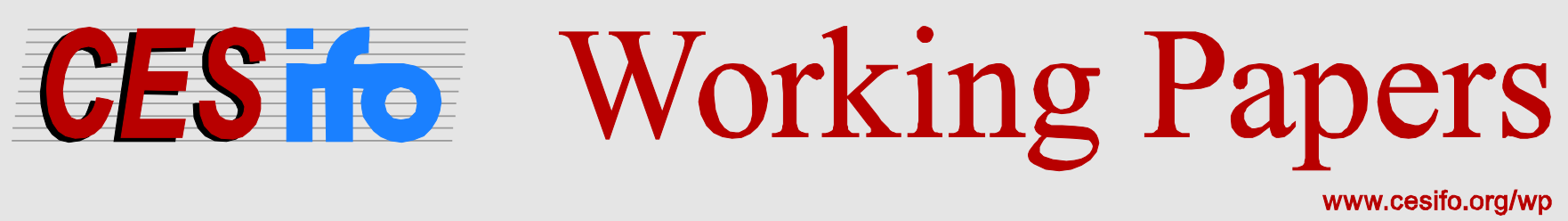

\title{
Academic Exclusion: Some Experiences
}

\author{
Arye L. Hillman \\ Heinrich W. Ursprung
}
CESIFO WORKING PAPER NO. 5912
CATEgory 2: Public CHOICE
MAY 2016
An electronic version of the paper may be downloaded
- from the SSRN website:
- from the RePEc website:
- from the CESifo website:
www.SSRN.com
Www.RePEc.org
www.CESifo-group.org/wp




\title{
Academic Exclusion: Some Experiences
}

\begin{abstract}
We describe and compare the experiences of academic exclusion of Alexander Del Mar, J.A. Hobson, and Gordon Tullock. While aspects of the circumstances differed, a common element was academic exclusion because of challenges to mainstream views. Alexander Del Mar, J.A. Hobson, and Gordon Tullock were in due course recognized for the originality and merit of their contributions, although each incurred personal costs because of the exclusion by the academic elites of their time. Our study takes us into the role of ideologically based prejudice in judgement of the worthiness of economic ideas.
\end{abstract}

JEL-Codes: A110, A140, B310, H110, P160.

Keywords: ideology, rents, rent seeking, X-efficiency, Gordon Tullock, Alexander Del Mar, J.A. Hobson, bias, eugenics, prejudice, anti-Semitism, professional recognition, strategic referencing.

\author{
Arye L. Hillman \\ Department of Economics \\ Bar-Ilan University \\ Israel - Ramat Gan 5290002 \\ arye.hillman@biu.ac.il
}

Heinrich W. Ursprung

Department of Economics

University of Konstanz

Germany-78457 Konstanz

Heinrich.Ursprung@uni-konstanz.de

May 2016 


\section{Introduction}

New ideas, ever if meritorious, are often resisted. It is usual for a prevailing paradigm to be protected until a new competing idea is confirmed as superior (Thomas Kuhn 1962 [2012]). Motives of self-interest can explain resistance to new ideas. Personal human capital is diminished by new ideas, the acceptance of which requires updating the contents of course materials and classroom lectures. New ideas that challenge religious dogma have been resisted. The Catholic Church excluded unwanted ideas by notification in an Index of Prohibited Books (discontinued in 1996). Dissenting thinkers were throughout the centuries punished by the Church, or in some cases escaped punishment by recanting. Galileo famously, in 1633, recanted his claim that the earth revolves around the sun (see Santillana 1955 on Galileo's heresy). Communism was vigilant in protecting its ideology and dealt harshly with critics (see, for example, Solzhenitsyn 1988). The 20 $0^{\text {th }}$ century's National Socialists banned ideas inconsistent with their ideology of Aryan racial superiority, but also went beyond banning ideas to acting inhumanely toward people caught in their grasp whom they deemed to be racially inferior. The National Socialists disparaged the writings of the 'inferior people'. Albert Einstein's theory of relativity was denounced as incorrect 'Jewish science' (Gimbel 2012). The harsh punishment of dissenters as by the Church, the Bolsheviks, and the National Socialists is impermissible in academia in a democracy. The web of control of adherents to a mainstream line of thought and the discretion imparted to journal editors and book publishers nevertheless can facilitate academic exclusion of unwanted ideas and unwanted people. We study and compare the academic exclusion, in terms of people and ideas, of three economists, Alexander Del Mar (1836-1926), J. A. Hobson (18581940), and Gordon Tullock (1922-2014). Each proposed ideas that ran counter to mainstream of economic thought. Although their ideas and they themselves were academically excluded, in due course all were acknowledged as having made innovative contributions of the highest merit.

Exclusion in academia differs from being criticized. Criticism is a compliment because of the indication that others regard an idea as worthy of 
attention and debate. Exclusion takes place by being shunted aside and ignored in mainstream academic interchange. Such was the case with Del Mar, Hobson, and Tullock. The academic exclusion of Del Mar, Hobson, and Tullock involved ideology, albeit in different ways. Economic ideas and ideology are closely associated (Dobb 1973). Ideology can be a means of expressing personal identity. For example, proclaiming oneself to be 'progressive' is a means of expressing an identity of being a kind and caring person (Hillman 2010). When identity is chosen through adherence to an ideology, reality can be disregarded. People can choose to believe what they want to believe (Caplan 2008). Joseph Schumpeter (1954) observed that 'the way in which we see things can hardly be distinguished from the way in which we wish to see them'. An ideologically preferred world can dismiss ideas that challenge the way in which the ideological mainstream wishes to see the world - and the way in which the ideological mainstream wishes the world to be seen by others. Scholars can be academically excluded because of personal association with ideas that an ideology does not want expressed. Individuals can also be excluded but not their ideas. Sensitive questions then arise. Has recognition been denied because of mainstream unfamiliarity with the excluded person's writings, or has there been strategic exclusion by design?

We begin in section 2 with Gordon Tullock. Section 3 describes the case of Alexander Del Mar and section 4 the case of J.A. Hobson. In section 5 we ask whether Del Mar, Hobson, and Tullock objectively merited awards of personal recognition that they were denied because of their exclusion from the academic mainstream.

\section{The academic exclusion of Gordon Tullock}

\subsection{The challenge to the mainstream}

In a paper published in 1967 in the Western Economic Journal (later renamed Economic Inquiry), Gordon Tullock introduced the idea that contestable rents are a source of social loss. Tullock observed that, while participation in a contest for access to rents can be beneficial personally (expected utility is positive), rent seeking creates a social loss because of the non-productive use of resources, or 
abilities, or talent and time, in contesting the rents. Tullock took the view that people would not be deterred from participating in socially unproductive quests for rents if there were personal benefits to be obtained. He proposed that 'people are people' (Tullock 2000), meaning that self-interest can in general be expected to motivate human behavior. The source of rents can be corruption (Hillman 2009, chapter 2; Aidt 2016). Whether or not corruption is involved, being a 'rent seeker' is not exemplary behavior. A 'rent seeker' sets out to benefit from the income or productiveness of others and rent seeking merely redistributes existing wealth. Progressive principles require people to want to be personally productive. In the parlance of communist ideology, rent seekers are unproductive and 'parasites'.

In proposing that 'rent seeking' takes place, Tullock contradicted the 'progressive' view of desirable human nature. At the same time, Tullock also challenged the premise of 'progressive' ideology that government generally is well-meaning and benevolent. Mainstream 'welfare economics' views governments as altruistically choosing income redistribution by maximizing a social welfare function (for example, $\mathrm{Ng} 2004$, chapter 6). Tullock proposed that the distribution of income is determined through contests for politically conferred privileges. Governments create the rents for which individuals and groups compete in unproductive ways, while the outcomes of the contests are not necessarily consistent with notions of social justice. Successful rent seekers need not be, and need not be expected to be, socially deserving of the benefits that the contests provide.

\subsection{Rents and X-efficiency}

Although Gordon Tullock's identification of social loss from contestable rents contradicted 'progressive' ideology in both portrayal of human nature and view of government, Tullock was not taking an ideological position. He was proposing an answer to the question of why empirical studies had found efficiency losses from monopoly and trade protectionism to be surprisingly small as measured by deadweight losses. Arnold Harberger (1954) had estimated the social cost of 
monopoly in the United States of 1929 to be $0.07 \%$ of GNP; no estimate for the United States or other countries of the social cost of monopoly or tariffs had exceeded $0.2 \%$ of GDP. Tullock observed that social losses from monopoly and protection were greater than deadweight losses because of the unproductive use of resources in contesting monopolistic and protectionist rents. He titled his paper making this point 'The welfare costs of monopoly, tariffs and theft' (Tullock 1967).

The paper was rejected for publication in 1966 at the profession's leading journal, the American Economic Review. A rejection at the AER is in itself neither notable nor exceptional. In his Shaftesbury Papers monograph on rent seeking, Tullock (1993, chapter 3) later pondered the negative reception received by his paper in light of the acceptance for publication in the AER in 1966 (the same year that Tullock's paper was rejected) of an article titled 'X-efficiency' by Harvey Leibenstein. Tullock and Leibenstein were addressing the same puzzle of the small empirical estimates of the social losses from monopoly and protection based on deadweight losses. Leibenstein pointed to additional social loss beyond deadweight losses because of individuals' not exerting full productive effort or not using resources as efficiently as possible. Leibenstein supported his X-efficiency idea with data from the International Labor Organization showing differences in labor productivity in the same industry in different countries. He interpreted the productivity differences as indicating discretionary effort (the data were from lowincome Asian countries and Israel). Leibenstein's theory of social loss attributable to insufficient personal motivation and effort applied generally to human nature. The AER's editor John Gurley, who handled the submission of Tullock's paper, accepted 'X-efficiency' for publication. ${ }^{1}$ Tullock was informed that, although the journal's reviewer had been unable to understand Tullock's point, publication of Tullock's paper was nonetheless not warranted because, in Gurley's view, the idea

${ }^{1}$ The ' $X$ ' in ' $X$-efficiency' is explained by Leibenstein's inability to identify precisely its source. 
of 'real resources devoted to establishing, promoting, destroying etc. monopoly ... does not seem significant enough' (emphasis added). ${ }^{2}$

A profound ideological distinction exists between Tullock's idea of welfare loss arising from contestable rents and Leibenstein's idea of 'X-efficiency'. Tullock attributed inefficiency to rent creation associated with the public policies of government that created monopoly and protectionist rents in the first place. Leibenstein attributed inefficiency to personal 'laziness' in monopolized or less than perfectly competitive markets. For Tullock, people were not 'lazy' but rather maximized expected utility in seeking to benefit from rent-seeking opportunities. Leibenstein's proposal of social loss because of insufficient personal motivation is consistent with motivational problems encountered in implementing communist principles. 'X-efficiency' as a concept justifies social engineering to compel unmotivated people to exert more effort and thereby to contribute to the social good according to their ability. ${ }^{3}$

\subsection{The ideological mainstream}

Tullock (1967) proposed that government-created rents are the source of social loss. Discretionary effort facilitated by monopoly in the private sector is the source of inefficiency for Leibenstein (1966). Tullock's proposal ran counter to the ideology of mainstream academic U.S. economics of the time. David Levy and Sandra Peart (2011) document how principles of 'progressive' interventionist ideology permeated leading U.S. economics textbooks in the second half of the $20^{\text {th }}$ century. A systematically favorable picture was presented of the Soviet economy. Levy and Peart (2011, p. 111) identify the circumstances as ideological monopoly

2 Tullock's paper was also rejected by Economica and the Southern Economic Journal. The $S E J$ 's editor did not quite understand Tullock's contribution and in his rejection letter misinterpreted Harberger (1954) as already having accounted for social losses attributable to the "rectangle" that measured monopoly profits. See Tullock (1993, p. 11).

${ }^{3}$ Friedrich von Hayek (1988) described belief in the possibility of successful social engineering as the Fatal Conceit. 
('competition among differing viewpoints was prematurely suppressed'). Mark Skousen (1997) correspondingly found persistent support for benevolentgovernment activist ideology in successive editions of Paul Samuelson's leading U.S. undergraduate economics textbook. Skousen observed that the 13th edition of Samuelson's textbook (1989), co-authored with William Nordhaus, included the declaration that 'the Soviet economy is proof that, contrary to what many skeptics had earlier believed, a socialist command economy can function and even thrive' (p. 837). The collapse of the Soviet Union and of communist Europe began that very year.

John Gurley, editor of the AER between 1963 and 1968, who accepted Leibenstein's idea of X-efficiency and rejected Tullock's proposal of social costs of contestable rents, was a prominent monetary and financial economist whose research (for example, Gurley et al. 1960) had earned him a full professorship at Stanford. Gurley had, in his early career, emphasized the beneficial role of financial markets in economic development (Gurley and Shaw 1955). Around the mid-1960s, Gurley appears to have begun a personal ideological transformation from the study of the capital markets, finance, and money of 'capitalism', to the study of communism, in particular the Maoist variant. In 1970 he published an appraisal of 'capitalist and Maoist economic development' in which he proposed that western economists underappreciated the virtues of Maoism. We quote from Gurley:

most studies by American economists of Chinese economic development are based on the assumption of capitalist superiority, and so China has been dealt with as though it were simply an underdeveloped United States -- an economy that "should" develop along capitalist lines and that "should" forget all that damn foolishness about Marxism, Mao's thought, Great Leaps, and Cultural Revolutions and just get on with the job of investing the savings efficiently. This almost complete and unthinking acceptance by American economists of the view that there is no 
development like capitalist development has resulted in studies of China that lack insight and are generally unsatisfactory.

Gurley achieved prominence for his views (for example, Gurley 1976a,b) on the merits of Maoism and is included in a compendium of western economists sympathetic to communist social and economic organization (Roberts and LaFollette 1990, p. 139):

In 1984 economist John Kenneth Galbraith was still writing that 'the Russian system succeeds because in contrast to the western industrial economy it makes full use of its manpower' ... As it became more difficult to see the future in the Soviet model, hopes shifted to the Maoist economy. In the early 1970s, John Gurley, distinguished Stanford economist and former editor of the American Economic Review, saw the future in Maoist China.

It is ironic that, as he was shifting from studying the financial markets that are the foundations of capitalism to finding virtue in communism, Gurley became interested in the type of economic system that is most prone to the behavior that Tullock had described in his theory of contestable rents. With markets absent and decisions that determine people's well-being made within a hierarchy of authority, the primary, or perhaps indeed only, means of seeking personal benefit under communism was by competing for benefits assigned through other people's decisions (Hillman and Schnytzer 1986; Anderson and Boettke 1997; Levin and Satarov 2000; Hillman 2009, section 2.3). Tullock's paper, if published, would have been a statement that rent-seeking behavior is at the core of economic systems in which market decisions are replaced by the governmental and planners' directives about which Gurley, Samuelson, and others enthused

\subsection{Ideology or technicality?}

Tullock considered the possibility that insufficient mathematical modeling or econometric evidence might be the reason for Gurley having rejected his paper. He noted that 'my 1967 article was simple, low tech and brief' (Tullock 1993, p. 
13). Leibenstein's exposition of X-efficiency was, however, also 'simple, low-tech and brief'. Editor John Gurley did not criticize Tullock's paper for being technically unsophisticated and he accepted for publication Leibenstein's paper that was equally technically unsophisticated. Gurley was explicit in stating that the reason for Tullock's rejection was not insufficient technicality in exposition, but that the idea of social loss from the contesting of rents lacked 'significance'.

\subsection{Acceptance of Tullock's idea}

X-efficiency persisted in the literature. The idea has been defended (for example, Perelman 2011). Critics of 'X-efficiency' view the idea as vague and as simply pointing to the existence of monitoring and principal-agent problems under asymmetric information (Stigler 1976). While X-efficiency lingered on as a marginal idea, Tullock's proposal of social loss from contesting of rents became a seminal concept in economics, with wide application to political economy and the theory of contests (see Congleton et al. 2008; Hillman 2013a; Long 2013; Congleton and Hillman 2015). Posner (1975) extended the social losses to non-price competition and the concept has been applied to rent creation in regulated industries (Shughart and Thomas 2015). Protectionist international trade policies are a case of creation of politically assigned rents (Hillman 1982; Grossman and Helpman 1994). If import quotas are used, rents are created for both the protected industry and for quota holders (Krueger 1974). In contests that transfer income, social losses include resources used in resisting rent seekers (Tullock 1971a; Appelbaum and Katz 1986). Rent seeking is present in democracies and in autocracies and ostensibly more so in the latter (Hillman and Ursprung 2016). A comprehensive theory of self-interested political behavior and privileged benefit emerges when rent seeking is extended to include sharing of rents of successful rent seekers with the political decision makers whose policies created the rents (Hillman 2015). Rent seeking has been studied as design of contests for political advantage (Appelbaum and Katz 1987; Gradstein and Konrad 1999; Epstein and Nitzan 2015) and has been placed into the context of behavioral economics (Shermeta 2015). Tullock's 1980 
paper 'efficient rent seeking' initiated study of the theory of contests (Konrad 2009). His probabilistic contest success function became known as the 'Tullock' function and has been studied and shown to have desirable axiomatic properties (Skaperdas 1996).

\subsection{Excluding the person}

We have described the exclusion of Tullock's idea. Tullock was also excluded personally. The exclusion of Tullock as a person was not necessarily associated with exclusion of his idea. With Tullock not necessarily acknowledged as the source, the idea of social loss from the quest for personal benefit from rents was acknowledged as important, by emulation or by emphasis. There are two prominent cases of personal exclusion of Tullock and not of his idea. One case involves Anne Krueger, who gave the name 'rent seeking' (Krueger 1974) to the activity of contesting rents that Tullock (1967) had described. In a second case, the personal exclusion of Tullock in conjunction with acceptance of his idea is associated with a broader literature known as the 'new' political economy.

\subsubsection{Political correctness and development policy advice}

Anne Krueger (1974), like Leibenstein, was given the forum of the AER for her study of the social cost of import quota rents. She did not refer to Tullock's 1967 paper. In an age before internet searches, Krueger's omission can be attributed to the exclusion of Tullock from mainstream academic journals. In 1990, on being awarded the Bernhard-Harms Prize at the Kiel Institute in Germany, Anne Krueger delivered a lecture on 'Economists' changing perceptions of government', published as Krueger (1990), in which she made the point that economists no longer viewed governments as necessarily benevolent. She again made no reference to Tullock. A 1980 compendium of papers (Towards a Theory of the RentSeeking Society, edited by Buchanan, Tollison, and Tullock 1980) set the idea of rent seeking on its course. A presumption that, at the time of her Bernhard-HarmsPrize lecture, Anne Krueger knew of Tullock's 1967 paper, is based on the 
reprinting of both her 1974 paper and Tullock's 1967 paper in the same 1980 compendium. It would have been more difficult not to acknowledge Tullock, had Tullock's paper, like Krueger's paper (and that of Leibenstein) been given the forum of the $A E R$.

What reason could Anne Krueger have had for not acknowledging Gordon Tullock's preceding contribution in her 1990 lecture and paper? Anne Krueger was not protecting an ideology: she herself had named 'rent seeking' and she acknowledged that governments created and dispensed rents. Gordon Tullock often applied his ideas on rents and political decisions to the United States (see, for example, Tullock 1991 on 'accidental freedom'). Anne Krueger (1974) studied rents created by governments in 'developing' low-income countries. As an applied international and development economist, she had the task, from high positions in the World Bank (as Chief Economist from 1982 to 1986) and the International Monetary Fund (as first deputy managing director from 2001 to 2006), of recommending socially beneficial economic policies to the governments of lowincome countries. It was common for the governments not to implement the recommended policies. In explaining incentives of governments not to follow beneficial policy advice, William Easterly (2001) pointed to a 'hostage' problem whereby governments kept the poor in their countries in poverty, with the aim of evoking more development aid. Tullock (1975) had made a similar point previously, using as background the theory of contests. He described contests for foreign aid as rent seeking in which the winners were the governments that were the most effective in impoverishing their populations. Studies (see Svensson 2000) also concluded that aid evoked internal rent seeking after a government had succeeded in winning externally provided resources.

Donors and the 'development community' have an interest in disassociation from the portrayal of rulers and elites in low-income countries as self-serving rent dispensers and rent seekers. In the consultative meetings of Anne Krueger and members of the 'development community' with representatives of governments of low-income countries, the presence of Gordon Tullock in the room, participating, and putting forth his views on how rulers in poor countries 
compete for aid by impoverishing their peoples and how aid attracts resources to domestic rent seeking, would have been unwelcome.

Tullock's rent-seeking idea was marginalized or kept outside the scope of the study of development economics, although rent seeking was endemic in lowincome countries (see Chen, Kang and Liu Qijung 2015; Marjit and Mukherjee 2015; Mbaku and Kimenyi 2015). The leading scholars in a field have usually been invited to contribute to Elsevier Handbook series. Between 1988 and 2008, four volumes of the Handbook of Development Economics were published by Elsevier. Volume 1 (1988) contained no references to rent seeking. Volume 2 (1989) contained six references to rent seeking (totally about one page of text). In volumes 3A and 3B (1995), 10 references to rent seeking can be found scattered over about five pages of text. Volume 4 (2008) again did not reference rent seeking at all. The volumes comprise some 4035 pages in total. The proportion of pages that mention rent seeking is readily calculable as 0.0037 .4

Tullock's views on aid ineffectiveness have been confirmed empirically (see Doucouliagos and Paldam 2008, 2011). His themes and conclusions came to be accepted among development economists interested in understanding the reality of aid - even if Tullock was not necessarily always present by name. Abed and Gupta (2002), for example, provide an IMF perspective on development failure that encompasses corruption and rent seeking.

\subsubsection{Exclusion through supersession}

Around the mid-1990s a group of influential scholars, often located in leading economics departments, re-addressed questions that earlier had been raised by the public choice school. Their contributions were labeled the 'new' political economy. They often reached much the same conclusions that had previously been set out in the public choice literature but tended to use more technical means of exposition

${ }^{4}$ See Paldam (1993). We thank Martin Paldam for the updates. 
than did public-choice scholars. The 'new' political economy evoked controversy: Charles Blankart and Gerrit Koester (2006) accused the scholars associated with the 'new' political economy school of replicating the contributions of the prior public-choice literature without due recognition. If Blankart and Koester were correct, members of the 'new' political economy school had behaved unprofessionally in not bothering to read prior literature. Alternatively, if scholars of the 'new' political economy were aware of past public choice contributions, exclusion had been by design. Exclusion by design can be ideological. The intent can also be to suggest originality. Jeong-Yoo et al. (2011) have described how rent seeking occurs in academia through strategic referencing. ${ }^{5}$

In their reply to the criticism by Blankart and Koester (2006), Torsten Persson, Guido Tabellini, and Alberto Alesina (2006), prominent contributors to the 'new' political economy literature, referred to the allegation of nonacknowledgment of past public-choice contributions, but also responded with the counterclaim that it was the public-choice school that was attempting academic exclusion, by defining a field of research in which public choice claimed special privilege and into which it did not want others to intrude:

"we don't really understand what specific ideas our critics oppose. Nor do we understand the issues that they raise, other than the alleged omission of adequate credit to some predecessors of our own work. To us, political economics is a branch of economics defined by the problems it studies, namely government behavior and the interaction between economics and politics. We look forward to learning from other economists, political scientists, or social scientists from other fields that work on these exciting problems, even if they pretend to belong to a special sect or elite. (Persson, Tabellini and Alesina 2006, p. 207; italics added)."

\footnotetext{
${ }^{5}$ On other forms of rent seeking in academia, see Brennan and Tollison (1980).
} 
The issue whether public choice is a 'sect' had been addressed previously. Martin Paldam (1993) asked the question whether public choice was a 'sect' or 'branch' of economics and concluded that 'public choice is a bit of both'. Paldam proposed that a 'strong sign of a sect is if the group-members have some special point of view that they alone find important' (p. 177).

Being a 'sect' can be explained by voluntary self-exclusion. A 'sect' can also be the consequence of exclusion by the mainstream for addressing questions that the mainstream does not want to have asked. Tullock raised the question, inconsistent with mainstream thought and ideology, of whether governments create contestable rents and was academically excluded. If Tullock was part of a 'sect', the 'sect' was not created by voluntary self-exclusion.

The primary issue is not, however, whether public choice is a sect and, if so, the reason why. The question raised by Blankart and Koester (2006) introduces the further question was whether the 'new' political economy was attempting supersession of public choice. With successful supersession, the new expositors of the 'new' ideas could replace the old expositors of the 'old ideas'. Students guided by the expositors of the 'new' ideas would not need to study the superseded public-choice texts.

Supersession of public choice would include supersession, through reattribution, of Tullock's idea of social loss from the use of time and ability in the socially unproductive contesting of rents. Reference to public choice and to Tullock has indeed been absent from various 'new' repetitions of Tullock's observation about the social loss from unproductive activity. As a case in point, we can consider the technically elegant exposition by Daron Acemoglu (1995, p. 18) of 'a simple model of allocation of talent between two activities; productive entrepreneurship and unproductive rent-seeking'. Acemoglu, winner in 2005 of the John Bates Clark Medal that is often a precursor to the Nobel Prize, modelled outcomes in which 'talent' is attracted to unproductive activities that he described as 'rent seeking'. No acknowledgment is made of the existence of Tullock's prior description of unproductive activities in which 'talent' could, from 
a social perspective, be wasted. Again, it would have been less likely that Tullock's original conceptual contribution would be - or could be - overlooked or set aside, had academic exclusion not occurred and had Tullock's 1967 paper been published in the AER. Perhaps Acemoglu was not aware of Tullock's original contribution, although, by the early 1990s, a substantial public-choice literature existed building on Tullock's observation of private incentives to engage in socially unproductive activity, or rephrasing 'wasted talent' (see Rowley et al. 1988). Whether or not by intention, Tullock (the person) was being subjected to attempted supersession.

Attempts at supersession often have been accompanied by prejudice against those who are declared to have been superseded. The declared superseded may not accept their supersession. A parallel is the claim of supersession made against the Jews and the Jews' successful resistance (see Hillman 2013b). Supersession can be completely effective, only if there is no opposition by those who are claimed to have been superseded.

\subsection{Technicality}

The 'new' political economy has been criticized on grounds other than attempted supersession. There is also a view that, although addressing the same or similar questions as has public choice, the 'new' political economy has over-emphasized technicality of exposition. The consequence has been mechanical analysis that stunts and restricts the broad enquiring spirit that has been characteristic of the public choice school (Ursprung 2002). Tullock commented on why researchers might want to maximize technicality of exposition (Tullock 1996, chapter 3):

if the field is one in which there are vastly more people (as a result of the necessity of staffing teaching posts in each field according to the number of students) than would appear justified by the likelihood of making discoveries of any significance, then there will be more pressure to make false discoveries or to present trivial discoveries as major. 
This kind of situation is one in which all of the people in the field are apt to be looking primarily for an opportunity to do something which can be made to look like research, and the reputation of journals is consequently likely to be dependent on the aid they give in this endeavor.

One symptom of the existence of this condition is the development of very complex methods of treating subjects which can be readily handled by simple methods. Calculus will be used where simple arithmetic would do, and topology will be introduced in place of plane geometry.

\section{Academic exclusion: The case of Alexander Del Mar}

Alexander Del Mar, like Gordon Tullock, challenged a prevailing mainstream economics view. Robert Mundell (2004) observed that 'Del Mar's ideas went against the grain of prevailing theories in economics'. The mainstream view in Del Mar's case was that the essence of money is in the value of the metals of which money is composed. Del Mar proposed that the purpose of money is to provide information by measuring value in terms of a numeraire or unit of account. He declared that this purpose could be served by any means that allowed a stable price level to be maintained. The role of whatever was acceptable as money was to convey information. Aschheim and Tavlas (2004, p. 35) quote Alan Meltzer:

I was very impressed with the fact that Del Mar was able to recognize long before Hayek, the information problem in economics. It took Karl Brunner and me years of discussion before we were able to resolve those issues in our mind for the $A E R$ paper we published in December 1971. It was therefore somewhat surprising to find that Del Mar had the main idea much earlier. 
Alexander Del Mar was excluded from U.S. academic literature (he did publish books in England). As did Tullock, De Mar founded his own journal. ${ }^{6}$

Del Mar subsequently was recognized as having made significant novel contributions to economic thought. Del Mar anticipated Irving Fisher's theory of interest. Fischer acknowledged Del Mar in his book 'The purchasing power of money' (revised 1922). Del Mar anticipated Keynes in pointing out the macroeconomic effects of domestic deflation:

although theoretically labour benefits from a general fall in prices (it being the last, in point of time, to feel the effects of a diminished sum of money), it practically suffers even more than during a general rise in prices, because a fall of prices hinders commerce and depresses production, and thus deprives labour of employment. ${ }^{7}$

Del Mar was nonetheless subject to academic exclusion. Aschheim and Tavlas (2004, p. 43) note that 'the almost complete absence of any acknowledgement of, and/or reference to his work by successive generations of American economists is noteworthy' and propose that the 'near-total disregard of Del Mar in the United States' as due to 'the failure of Del Mar's contemporaries to acknowledge his contributions, which led to his neglect by almost all subsequent writers, including authors of textbooks on the history of thought'.

Aschheim and Tavlas assign a principal role in in the silencing of Alexander Del Mar to

three eminent figures in the history of American economics, David Wells (1828-1898), Francis A. Walker (1840-1897), and Henry George (1839-1897). Each was instrumental in popularizing and shaping the study of political economy in the United States in the

${ }^{6}$ Del Mar's co-founded journal was The New York Social Science Review: Devoted to Political Economy and Statistics.

${ }^{7}$ Del Mar (1896, p. 188), cited by Aschheim and Tavlas (2004, p. 38). 
late 19th century. None of them ever referred to Del Mar. Unlike subsequent writers, however, it cannot be said that they were unaware of either the man or his work.

As with Gordon Tullock, exclusion of Del Mar's ideas and also exclusion of the person is evident. Alexander Del Mar had to contend with personal exclusion because of anti-Semitism. Milton Friedman observed that 'the Del Mar case is striking and I have no doubt that it is a question of anti-Semitism'. ${ }^{8}$ Lawrence Klein (2004) also viewed the silencing of Alexander del Mar as due to anti-Semitic prejudice. The 'science' of eugenics, which at the time of Del Mar had mainstream acceptance, specified a hierarchy of competence of peoples or races. Jews were assigned an intellectually inferior status (see Peart and Levy 2005). The inferior status was inconsistent with Del Mar, as a Jew, making scientific contributions of worth that needed to be seriously considered. ${ }^{9}$

\section{Academic exclusion: The case of J. A. Hobson}

J. A. Hobson (1858-1940) was also the victim of academic exclusion. Hobson's support for socialist ideology was unacceptable to his peers (see Fiona Maclachlan 2002/3). Although he was from an upper-class family and had been educated at Oxford, Hobson's ideological perspective was sympathetic to the plight of the poor. He regarded markets as intrinsically unfair because of asymmetries in

${ }^{8}$ Quoted by Aschheim and Tavlas (2004, p. 31).

${ }^{9}$ Francis A. Walker, mentioned above, was, as a metalist, an opponent of Alexander del Mar's view of money. Walker was the first president of the American Economic Association (1886-1892), president of the American Statistical Association (1882-1897), vice president of the National Academy of Sciences in 1890, and president of MIT (1881-1897). Walker was an adherent of the principle of a racial hierarchy of ability and competence (see Aschheim and Tavlas, p. 51). Racial prejudice based on 'eugenics' also was directed at African-Americans. William Darity (1994) documents racial prejudice in the early American economics profession towards African-Americans in terms of views of their purported racially inferior personal capabilities and the prediction that in due course African-Americans would disappear from the United States or become marginalized, as had the indigenous Native American population (also see the observations of Warren Young 2004). 
bargaining power of buyers and sellers. Sellers were fewer than buyers in product markets and buyers were fewer than sellers in labor markets, in each case giving capital bargaining advantages over consumers or workers. Hobson challenged mainstream economic thought on business cycles, proposing that economic downturns were the consequence of 'under-consumption'. He was a critic of Say's Law. His view differed from, but was similar to, that of Keynes, who mentioned him.

For Keynes, insufficient investment was the reason for unemployment. Additional investment by government was the required policy if the private sector failed to provide adequate investment. Hobson proposed that overinvestment by capitalists created excess capacity and resulted in 'under-consumption', which could be ameliorated or resolved by redistributing income from the rich to the poor. The redistribution would increase demand through the greater spending of the poor. Hobson was criticized on the grounds that his theory and policy conclusions discouraged thrift and encouraged consumption. He was regarded by Alfred Marshall and Joseph Schumpeter simply as inadequately educated in economics.

Hobson's ideology was reflected in his conclusions drawn from his on-site presence as a correspondent during the Boer War. He regarded the war as instigated for capitalist gain. His book 'Imperialism' (1902) was regarded with favor by Lenin and his views on international capitalist expansion as exploitative were similar to those of Rosa Luxemburg. ${ }^{10}$

Hobson also was a believer in eugenics and an open anti-Semite. He described imperialism as the quest for profit by Jewish capitalists. In Southern Africa, Hobson described Cecil Rhodes as engaged in a capitalist conspiracy, with Jews, not Englishmen, as partners. Kaarsholm (1982, p. 6) quotes Hobson as taking the position that: 'The first provision for a sound society is that its citizens shall be well born', which is one of Hobson's milder statements relating to eugenics and

10 On the ideology of Rosa Luxemburg, see for example Lee (1971). 
the hierarchy of races. It is noteworthy that Hobson cared about the poor and downtrodden, as long as they were not Jews; his prejudice against Jews was grounded on accumulation of capitalist wealth. A visit to neighborhoods in London, Manchester, and other English cities would have made clear that many Jews were poor and far from being rich 'exploitative' capitalists. Anti-Semitism would not have been a reason for Hobson's academic exclusion. ${ }^{11}$

\section{Judging merit}

\subsection{Responding to exclusion}

How did Del Mar, Hobson, and Tullock respond to the exclusion of their ideas and their personal exclusion? Del Mar was forthright in responding to anti-Semitic prejudice (see Mundell 2004). He was equally forthright in commenting on the academic exclusion of his ideas:

The whole modern school of political economy ... (consists of) ... sophistical arguments, ... dismal conclusions, ... execrable jargon, and its unmeasured conceit and impudence.... Political economy falsely argues that money is and must be a commodity.... Upon this ... foundation there has been reared a tottering superstructure of sophistry, which, masquerading through the world in the false guise of science, has filled the schools and the legislative halls of every modern State with doctrines which bear about the same relation to "societary" life that mediaeval astrology did to the heavens. ${ }^{12}$

Hobson lectured at the Workers' Education Society, which offered evening classes for those who did not have the means or opportunity to undertake a

11 Anti-Semitism was culturally acceptable and mainstream for Hobson's time. For example, on Keynes, see Reder (2000).

12 Del Mar (1889, p. 227), cited by Aschheim and Tavlas (2004, p. 48). 
university education. In his memoires, 'Confessions of an Economic Heretic' (1938), he lamented not having had the company of scholars and wondered whether objectivity was at all possible in political economy. He observed that refusal to debate is a means of exclusion:

the best weapon is a refusal to discuss, or to refute, because the issue is already settled and beyond dispute. (Hobson 1938, p. 11)

He also noted how emotions prevent intellectual discussion:

in the more exact sciences, where false or outworn laws or hypotheses can definitely be refuted and replaced by others, there is little of that emotional strain that comes when an economic law or a political principle is challenged. (ibid, p. 12)

Gordon Tullock suggested hypocrisy by the progressive intellectual mainstream. In 1971, Tullock published a paper with the title 'The charity of the uncharitable'. The paper was published in the Western Economic Journal, which had also published his 1967 paper on contestable rents. In the 'The charity of the uncharitable', Tullock asked why intellectuals - and in particular university professors -- do not give to charity personally and directly, but rather preach reliance on government for income transfers to the poor. He noted the argument that reliance on government broadens the base for giving to include all taxpayers, but proposed that intellectuals, especially university professors, confront cognitive dissonance caused by the internal conflict of wishing to keep their incomes for themselves while at the same wishing to regard themselves as charitable. The conflict is resolved by voting for charity rather than donating money personally. In voting for charity, a small cost of time is incurred. Voting to give is therefore less costly than actually giving money personally. Tullock explained:

If I am possessed both of selfish desires to spend my own money and a feeling that I must be charitable, I am wise to vote charitably and act selfishly. I should also tend, in discussion, to put much greater weight upon the importance of my vote than is actually 
justified, and to resent people who tell me that the vote makes no difference. At this point, the rationale for the ethical rule that private charity is bad and that all redistribution should be public becomes apparent. It provides a rationalization for 'ethical' behavior in urging government redistribution while actually making no sacrifice. It permits me to have the best of all worlds. (p. 272) 13

Tullock proposed that internal tension did not apply generally in the population (certainly not to 'blue-collar workers'). The 'progressive left' could therefore proclaim the superiority of the ideology of assigning preeminence to government income transfers, and could vote for generous redistribution through government, but anticipating and hoping being in the minority. The generous welfare policies will then not be implemented and the adherents to the 'progressive left' ideology will not need to pay the taxes that would be required to finance the generous income-transfer policies for which they voted. ${ }^{14}$

Tullock thus accused the 'progressive left' of being charitable only through their low-cost, non-decisive vote. The intellectuals were 'uncharitable' because they wished their vote alone to suffice as the act of charity. Tullock observed that his analysis was descriptive and not normative, but added: 'I fear, however, that the bulk of my readers will feel that it is essentially a denunciation of what I have described'. And a denunciation it was. Tullock anticipated the response of being ignored. The response of the progressive intellectuals would be 'simply to deny

${ }^{13}$ Page numbers refer to the reprinted paper in Rowley (2005).

14 Tullock was describing low-cost expressive voting. See Brennan and Brooks (2013). If the 'progressive' voters described by Tullock happened to be in the majority, they would find themselves in an 'expressive-policy trap' (see Hillman 2010). 
that it is true and go on happily reducing cognitive dissonance by the combination of being selfish in private expenditures and "generous" in politics' (p. 275).

Beyond the claim of 'progressive' hypocrisy, Tullock also would not have endeared himself to the core of the academic economics profession by his proposal that excessive technicality was a substitute for the inability of mathematicians who made their careers in economics departments to come up with ideas of substance.

\subsection{Individual differences in exclusion}

Del Mar, Hobson, and Tullock differed in aspects of their experiences of academic exclusion. Del Mar was denied academic recognition in the United States but published books in England and was appointed in 1866 to be the first Director of the US Bureau of Statistics, which was then part of the US Treasury Department. He initiated the collection of economic data by the US Treasury. J. A. Hobson was relegated to teaching at a night school for workers, while seeing his brother become a professor of mathematics at Cambridge. Hobson co-authored a successful textbook, published some 50 books, and published outside of England in the Journal of Political Economy and the Quarterly Journal of Economics. Tullock had the avenue of publication of the journal Public Choice that he founded, which became the leading counter-mainstream journal in insisting that self-interest prevails in government as well as in markets. Tullock also had the intellectual support of public-choice scholars. He published extensively in journals other than Public Choice and was made a Distinguished Fellow of the American Economic Association in 1998.15

15 On Tullock's various contributions, see Congleton (2004), Rowley (2005, 2012), and Shughart and Tollison (2016). 


\subsection{Prejudice and ideology}

The experiences of Del Mar, Hobson, and Tullock raise the question of whether a prejudiced judge can overcome personal bias and judge objectively? Sandra Peart and David Levy (2004, p. 87) observed that:

We allow that prejudice infects the academy in the area of personal relationships, acknowledging, for instance, that a scholar might oppose hiring a talented colleague because of racial or religious prejudice. Yet we often cling to the belief that the same scholar would be unbiased in the evaluation of ideas or intellectual output that he or she would never ignore or disparage ideas for racial or religious reasons. (Italics in the original)

The observation was made against the background of the prejudice imparted by a belief in eugenics. Del Mar went against the economic mainstream, but eugenics was used to make the case that Del Mar could not, in being Jewish, have original or useful ideas. In the case of Hobson, opposition to his economic ideas was against the background of mainstream rejection of the socialist ideology that he espoused. Hobson was perhaps too explicit and went too far in identifying with socialist ideology. Keynes also proposed that markets could malfunction and that government intervention was necessary to escape situations of low-demand and high unemployment.

In the case of Gordon Tullock, ideology was at the core of academic and personal exclusion. Tullock dared challenge the existence of the world that 'progressives' wanted to believe ought to be. What if, as followed from Tullock's theory of contestable rents, social welfare functions do not guide political distribution, but rather political distribution is contestable through political rent creation and rent assignment? What if redistribution by government, even in democracies, involves discretionary rent assignment by politicians using to advantage rational ignorance and economic illiteracy of the public? What if a majority rent-seeking and rent-dispensing coalition controls the benefits from the 
welfare state (Paldam 2015)? What if the autocratic governments of low-income countries compete for aid by keeping their populations poor, and what if aid, once given (or won), attracts domestic resources that are socially wasted in contesting who in the country will benefit from the aid? What if, in these contests, the privileged strong consistently win out over the disadvantaged weak (Hillman 2004)? In pointing to the presence of policy-created contestable rents, Tullock challenged the view that government should have a significant role in society. He raised questions about the merits of the social-democratic welfare state. He also undermined justification for the existence of international aid agencies, and fees for consultants.

\subsection{The reward of recognition}

Del Mar's theories became mainstream, including his view of money. Hobson's ideas were influential in the creation of the welfare state. Gordon Tullock's idea of social loss from contestable rents became one of the most significant theoretical and applied concepts of 20th century economics. Were Del Mar, Hobson, and Tullock worthy of the highest forms of professional recognition? ${ }^{16}$

Mundell (2004) and Klein (2004), both Nobel Prize winners in economics, praised the prescience and originality of the contributions of Del Mar. Would Alexander Del Mar have been awarded the Nobel Prize, had the Prize existed at his time? Del Mar was outspoken and unapologetic regarding those who had silenced him. He was also subject to the prejudice of proclaimed racial inferiority. Tullock was subject to prejudice by 'progressives' who claimed moral superiority by inventing and defending their vision of an ideal world. The gulags did not deter Samuelson's praise of a planned economic system that, by planning's necessary

${ }^{16}$ Tullock was involved in one of the more inexplicable cases of award of academic merit, with regard to the Calculus of Consent (Buchanan and Tullock 1962). See Shughart and Tollison (2016). We focus here on his contribution in initiating and developing the idea of social loss from contestable rents. 
rule of 'experts', denied personal freedom. In a twist of fate, Hobson proclaimed the merits of the ideology whose adherents excluded Tullock academically. Hobson was a progressive at a time when the English upper classes did not provide equality of opportunity and social mobility was too limited to allow escape from humble origins. Hobson betrayed his class to champion an ideology that justified the social-democratic welfare state. We can conjecture that, if judges of merit were sympathetic to the welfare state, from amongst our academically excluded economists, Hobson would have been rewarded with recognition such as now is provided through the Nobel Prize. Given the times at which they lived, the requirement of being alive makes the question of Nobel recognition for Del Mar and J. A. Hobson hypothetical. Only Gordon Tullock could have been acknowledged and rewarded.

\section{Post-script}

We submitted a paper focusing only on the academic exclusion of Gordon Tullock to the Journal of Economic Perspectives in September 2015. A primary point of our paper is the contrast between the acceptance of Harvey Leibenstein's paper on X-efficiency in the American Economic Review during the same year Tullock's paper on the social cost of contestable rents was rejected. In the present article, we have referred to the influence of ideology on academic exclusion. After our submission, we were informed quickly that submissions to the Journal of Economic Perspectives are in general invited and that there was no interest in publishing our manuscript. A subsequent request for a reason for our rejection resulted in the reply that explanations for rejection of non-submitted papers are not provided to authors. After asking again, we were informed that the Journal of Economic Perspectives had only recently published a retrospective paper. An implicit quota had therefore been filled. We believe it to be ironic that the accepted retroactive paper was on the merits of X-efficiency (Perelman 2011). When we pointed out this irony to the editorial office, we were informed that our paper also did not qualify for publication in the Journal of Economic Perspectives for more intrinsic reasons having to do with style and expression. We proceeded to extend the paper to a 
more general study of academic exclusion and in early April 2016 again submitted to the Journal of Economic Perspectives. There had been no request for resubmission but we now had written a new paper on the general theme of academic exclusion. The first submission had not reached the editors for evaluation. This time we escaped the equivalent of a desk rejection and the paper was sent to the editors. We were again informed that the Journal of Economic Perspectives was not interested in publishing our uninvited submission.

It is attributed to Gordon Tullock that he believed that authors should give the history of rejections of their papers, as he indeed was want to do. In memory of Gordon Tullock, we have here done as he proposed.

\section{Acknowledgements}

We have benefited from observations by Geoffrey Harcourt, Steven Husted, Fiona Maclachlan, Elias L. Khalil, David Laidler, Martin Paldam, William Shughart II, George Tridimas, and Viktor Vanberg. We also thank for their comments participants in sessions of the 2015 Australasian and the 2016 European Public Choice Conferences and seminars at the University of Pittsburgh, Monash University, and the University of New England.

\section{References}

Abed, G. T., \& Gupta, S. (2002). Governance, corruption, and economic performance. International Monetary Fund, Washington DC.

Acemoglu, D. (1995). Reward structures and the allocation of talent. European Economic Review, 39, 17-33.

Aidt, T. S. (2016). Rent seeking and the economics of corruption. Constitutional Political Economy, 27, 142-157.

Anderson, G. M., \& Boettke, P. J. (1997). Soviet venality: A rent-seeking model of the communist state. Public Choice, 93, 37-53. 
Appelbaum, E., \& Katz, E. (1986). Transfer seeking and avoidance: On the full social costs of rent seeking. Public Choice, 48, 175-181.

Appelbaum, E., \& Katz, E. (1987). Setting rents by seeking rents: The political economy of rent seeking. The Economic Journal, 97, 685-609. Reprinted in: Congleton, R. D., Hillman, A. L. \& Konrad, K. A. (Eds.) (2008), Forty years of research on rent seeking 1 - Theory of rent seeking. Heidelberg: Springer, pp. 555-569.

Aschheim, J., \& Tavlas, G. S. (2004). Academic exclusion: The case of Alexander Del Mar. European Journal of Political Economy, 20, 31-60.

Blankart, C. B., \& Koester, G. (2006). Political Economics versus Public Choice: Two views of political economy in competition. Kyklos, 59, 171-200.

Brennan, G., \& Brooks, M. (2013). Expressive voting. In Reksulak, M., Razzolini, L., \& Shughart, W. F. II (Eds.), The Elgar companion to Public Choice. 2nd edition. Cheltenham UK: Edward Elgar, pp. 111-126.

Brennan, G., \& Tollison, R. D. (1980). Rent seeking in academia. In Buchanan, J. M., Tollison, R. D. \& Tullock, G. (Eds.). Toward a theory of the rent-seeking society. College Station TX: Texas A\&M Press, pp. 344-356.

Buchanan, J. M., \& Tullock, G. (1962). The calculus of consent: Logical foundations of constitutional democracy. Ann Arbor MI: University of Michigan Press.

Caplan, B., (2008). The myth of the rational voter: Why democracies choose bad policies. Princeton NJ: Princeton University Press.

Congleton, R. D. (2004). The political economy of Gordon Tullock. Public Choice, 121, 213-238.

Congleton, R. D., \& Hillman, A. L. (Eds.) (2015). Companion to the political economy of rent seeking. Cheltenham UK: Edward Elgar.

Congleton, R. D., Hillman, A. L., \& Konrad, K. A. (Eds.) (2008), 40 Years of research on rent seeking: volume 1 - Theory of rent seeking, volume 2 - Applications: Rent seeking in practice. Heidelberg: Springer. 
Darity, W. Jr, 1994. Many roads to extinction: Early AEA economists and the black disappearance hypothesis. History of Economics Review, 21, 47- 64.

De Santillana, G., (1955). The crime of Galileo. Chicago IL: University of Chicago Press.

Del Mar, A. (1889). Money and civilization. London UK: George Bell.

Del Mar, A. (1896). The science of money. 2nd Edition. London UK: George Bell.

Dobb, M. (1973). Theories of value and distribution since Adam Smith: Ideology and economic theory. Cambridge UK: Cambridge University Press.

Doucouliagos, H., \& Paldam, M. (2008). Aid effectiveness on growth: a meta study. European Journal of Political Economy, 24, 1-24.

Doucouliagos, H., \& Paldam, M. (2011). The ineffectiveness of development aid on growth: An update. European Journal of Political Economy, 27, 399-404.

Easterly, W. (2001). The elusive quest for growth: Economists' adventures and misadventures in the tropics. Cambridge MA: MIT Press.

Epstein, G. S., \& Nitzan, S. (2015). Contestable policies. In Congleton, R. D. \& Hillman, A. L. (Eds.), Companion to the political economy of rent seeking. Cheltenham UK: Edward Elgar, pp. 53-72.

Gimbel, S. (2012). Einstein's Jewish science: Physics at the intersection of politics and religion. Baltimore MD: John Hopkins University Press.

Gradstein, M., \& Konrad, K. A. (1999). Orchestrating rent-seeking contests. Economic Journal, 109, 536-545. Reprinted in: Congleton, R. D., Hillman, A. L., \& Konrad, K. A. (Eds.) (2008), 40 Years of research on rent seeking: Theory of rent seeking. Heidelberg: Springer, pp. 571-580.

Grossman, G. M., \& Helpman, E. (1994). Protection for sale. American Economic Review, 84, 833-850. Reprinted in: Congleton, R. D., Hillman, A. L., \& Konrad, K. A. (Eds.) (2008), Forty years of research on rent seeking. Applications: Rent seeking in practice. Heidelberg: Springer, pp. 131-148. 
Gurley, J. G., \& Shaw, E. S. (1955). Financial aspects of economic development. American Economic Review, 45, 515-538.

Gurley, J. G., Shaw, E. S., \& Enthoven, A. C. (1960). Money in a theory of finance. Washington DC: Brookings Institution.

Gurley, J. G. (1970). Capitalist and Maoist economic development. Bulletin of Concerned Asian Scholars, Vol. 2. Available at: http:// scholar.googleusercontent.com/scholar?q=cache:DHuirVpSlz8J:sc

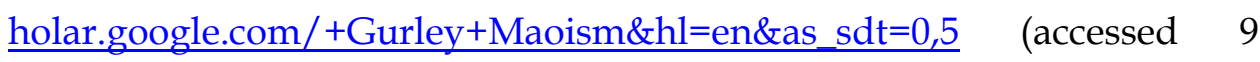
September 2015).

Gurley, J. G. (1976a). China's economy and the Maoist strategy. Monthly Review Press: New York \& London.

Gurley, J. G. (1976b). Challenges to capitalism: Marx, Lenin and Mao. San Francisco CA: San Francisco Book Co.

Harberger, A. C. (1954). Monopoly and resource allocation. American Economic Review, 44, 77-87.

Hayek, F. A. von (1988). The fatal conceit: The errors of socialism. W.W. Bartley III (Ed.). London UK: Routledge.

Hillman, A. L. (1982). Declining industries and political-support protectionist motives. American Economic Review, 72, 1180-1187. Reprinted in: Ethier, W. J. \& Hillman, A. L. (Eds.), The WTO and the political economy of trade policy. Cheltenham UK: Edward Elgar, pp. 43-50.

Hillman, A. L. (2004). Nietzschean development failures. Public Choice, 119, 263 280.

Hillman, Arye L. (2009). Public finance and public policy: Responsibilities and Limitations of Government. 2nd Edition. New York NY: Cambridge University Press. 
Hillman, A. L. (2013a). Rent seeking. In Michael Reksulak, Laura Razzolini, \& William F. Shughart II (Eds.), The Elgar Companion to Public Choice. 2nd edition. Edward Elgar, Cheltenham U.K., pp. 307-330.

Hillman, A. L. (2013b). Economic and behavioral foundations of prejudice. In Charles S. Small (Ed.), Global antisemitism: A crisis of modernity, Leiden, Netherlands and Boston MA: Martinus Nijhoff Publishers, pp. 51-67. Available at:

http://www.osservatorioantisemitismo.it/wpcontent/uploads/2014/05/01_ISGAP_Vol.-I_120114_Web.pdf\#page=61. Accessed May 6, 2016.

Hillman, A. L. (2015). Rent seeking as political economy. In: Congleton, R. D. \& Hillman, A. L. (Eds.). Companion to the political economy of rent seeking. Cheltenham UK: Edward Elgar, pp. 10-18.

Hillman, A. L., \& Schnytzer, A. (1986). Illegal economic activities and purges in a Soviet-style economy: A rent-seeking perspective. International Review of Law and Economics, 6, 87-99. Reprinted in: Congleton, R. D., Hillman, A. L., \& Konrad, K. A. (Eds.) (2008), Forty years of research on rent seeking. Applications: Rent seeking in practice. Heidelberg: Springer, pp. 545-557.

Hillman, A. L., and Ursprung, H. W. (2016). Where are the rent seekers? Constitutional Political Economy, 27, 124-141. Special issue in memory of Gordon Tullock.

Hobson, J. A. (1900). The war in South Africa. Its causes and effects. London UK: James Nisbet and Co.

Hobson, J. A. (1902). Imperialism, a study. Marked up by Einde O'Callaghan for the Marxists' Internet Archive. Available at: https://www.marxists.org/archive/hobson/1902/imperialism/intro.ht m. Accessed 21 January 2016.

Hobson, J.A. (1938). Confessions of an economic heretic. London UK: G. Allen \& Unwin Ltd.. Republished 2012 by Routledge, London UK. 
Kaarsholm, P. (1982). Imperialist ideology, romantic anti-capitalism and J. A. Hobson. African Studies Seminar Paper. University of the Witwatersrand, Johannesburg. Available at:

http://146.141.12.21/bitstream/handle/10539/8820/ISS209.pdf?sequence=1. Accessed January 21, 2016.

Kim, Jeong-Yoo, Insik Min, \& Zimmermann, C. (2011). The economics of citation. The Korean Economic Review, 27, 93-114.

Klein, L. R. (2004). Comment on academic exclusion: the case of Alexander Del Mar. European Journal of Political Economy, 20, 69-71.

Konrad, K. A. (2009). Strategy and dynamics in contests. Oxford UK: Oxford University Press.

Krueger, A. O. (1974). The political economy of the rent-seeking society. American Economic Review, 64, 291-303. Reprinted in: Congleton, R. D., Hillman, A. L., \& Konrad, K. A. (Eds.) (2008), Forty years of research on rent seeking. Applications: Rent seeking in practice. Heidelberg: Springer, pp. 151-63.

Krueger, A. O. (1990). Economists' changing perceptions of government. Weltwirtschaftliches Archiv, 126, 417-431. Bernhard-Harms Prize lecture, Kiel Institute.

Kuhn, T. (1962 [2012]). The structure of scientific revolutions. Chicago IL: University of Chicago Press.

Lee, G. (1971). Rosa Luxemburg and the impact of imperialism. Economic Journal, $81,847-862$.

Leibenstein, H. (1966). Allocative efficiency vs. X-efficiency. American Economic Review, 56, 392-415.

Levin, M. I., \& Saratov, G. A. (2000). Corruption and institutions in Russia. European Journal of Political Economy, 16, 113-132.

Levy, D. M., \& Peart, S. J. (2004). Statistical prejudice: From eugenics to immigrants. European Journal of Political Economy, 20, 5-22. 
Levy, D. M., \& Peart, S. J. (2011). Soviet growth and American textbooks: An endogenous past. Journal of Economic Behavior and Organization, 78, 110-125.

Long, N. V. (2013). The theory of contests: A unified model and review of the literature. European Journal of Political Economy, 32, 161-181. Reprinted in: Congleton, R. D. \& Hillman, A. L. (Eds.) (2015). Companion to the political economy of rent seeking. Cheltenham UK: Edward Elgar, pp. 19-52.

Maclachlan, F. (2002-3). J.A. Hobson and the economists. Journal of Post Keynesian Economics, 25, 297-308.

Marjit, S., \& Mukherjee, V. (2015). Market liberalization and rent seeking in India. In: Congleton, R. D. \& Hillman, A. L. (Eds.). Companion to the political economy of rent seeking. Cheltenham UK: Edward Elgar, pp. 410-420.

Mbaku, J. M., \& Kimenyi, M. S. (2015). Rents and development failure in Africa. In: Congleton, R. D. \& Hillman, A. L. (Eds.). Companion to the political economy of rent seeking. Cheltenham UK: Edward Elgar, pp. 371-394.

Mundell, R. (2004). Comment on academic exclusion: the case of Alexander Del Mar. European Journal of Political Economy, 20, 61-68.

Ng, Y-K. (2004). Welfare economics. Houndmills UK: Macmillan.

Paldam, M. (1993). More of a branch or more of a sect? Public Choice, 77, 177-184.

Paldam, M. (2015). Rents in a welfare state. In: Congleton R. D. \& Hillman, A. L. (Eds.), Companion to the Political Economy of Rent Seeking, Cheltenham UK: Edward Elgar, pp. 328-349.

Peart, S. J. \& Levy, D. M. (2004). The vanity of the philosopher: From equality to hierarchy in post-classical economics. Ann Arbor MI: University of Michigan Press.

Perelman, M. (2011). Retrospectives: X-Efficiency. Journal of Economic Perspectives, 25: 211-22. 
Persson, T., Tabellini, G., \& Allesina, A. (2006). Reply to Blankart and Koester's Political Economics versus Public Choice: Two views of political economy in competition. Kyklos, 59, 201-208.

Posner, R. A. (1975). The social costs of monopoly and regulation. Journal of Political Economy, 89, 807-827. Reprinted in: Congleton, R. D., Hillman, A. L., \& Konrad, K. A. (Eds.) (2008), Forty years of research on rent seeking. Applications: Rent seeking in practice. Heidelberg: Springer, pp. 45-65.

Reder, M. W. (2000). The anti-Semitism of some eminent economists. History of Political Economy, 32, 833-856

Roberts, P. C., \& LaFollette, K. (1990). Meltdown: Inside the Soviet economy. Washington DC: Cato Institute.

Rowley, C. K. (2012). The intellectual legacy of Gordon Tullock. Public Choice, 152, 29-46.

Rowley, C. K. (Ed.), 2005. The selected works of Gordon Tullock, volumes 1-10. Indianapolis IN: Liberty Fund.

Rowley, C. K., \& Houser, D. (2012). The life and times of Gordon Tullock. Public Choice, 152, 3-37.

Rowley, C. K., Tollison, R. D., \& Tullock, G. (1988). The political economy of rent seeking. Boston and Dorchrecht: Kluwer Academic Publishers.

Schumpeter, J. A. (1954). History of Economic Analysis. New York NY: Oxford University Press.

Shermeta, R. (2015). Behavioral dimensions of contests. In: Congleton, R. D. \& Hillman, A. L. (Eds.) (2015). Companion to the political economy of rent seeking. Cheltenham UK: Edward Elgar, pp. 150-164.

Shughart, W. F. II \& Thomas, D. W. (2015). Regulatory rent seeking. In: Congleton, R. D., \& Hillman, A. L. (Eds.) (2015). Companion to the political economy of rent seeking. Cheltenham UK: Edward Elgar, pp. 167-186. 
Shughart, W. F. II \& Tollison, R. D. (2016). The extraordinary life and times of Gordon Tullock. Constitutional Political Economy, 27, 227-247.

Skaperdas, S. (1996). Contest success functions. Economic Theory, 7, 283-290. Reprinted in: Congleton, R. D., Hillman, A. L., \& Konrad, K. A. (Eds.) (2008), 40 Years of research on rent seeking: Theory of rent seeking. Heidelberg: Springer, pp. 263-270.

Skousen, M. (1997). The perseverance of Paul Samuelson's Economics. Journal of Economic Perspectives, 11(2), 137-152.

Solzhenitsyn, A. (1988). The Gulag Archipelago 191 8-1956: An experiment in literary investigation-volume one. Boulder CO: Westview Press.

Stigler, G. J. (1976). The Xistence of X-efficiency. The American Economic Review, 66, 213-216.

Svensson, J. (2000). Foreign aid and rent seeking. Journal of International Economics 51, 437-461. Reprinted in: Congleton, R. D., Hillman, A. L., \& Konrad, K. A. (Eds.) (2008), Forty years of research on rent seeking. Applications: Rent seeking in practice. Heidelberg: Springer, pp. 165-189.

Tullock, G. (1967). The welfare costs of tariffs, monopolies and theft. Western Economic Journal, 5, 224-332. Reprinted in: Congleton, R. D., Hillman, A. L., \& Konrad, K. A. (Eds.) (2008), 40 Years of research on rent seeking: Theory of rent seeking. Heidelberg: Springer, pp. 45-53.

Tullock, G. (1971a). The cost of transfers. Kyklos, 24, 629-643. Reprinted in: Buchanan, J. M., Tollison, R. D. \& Tullock, G. (Eds.), (1980). Toward a theory of the rent-seeking society. College Station TX: Texas A\&M Press, pp. 269-282.

Tullock, G. (1971b). The charity of the uncharitable. Western Economic Journal, 9, 379-392. Reprinted in: Rowley, C. K. (Ed.), 2005. The Selected Works of Gordon Tullock, volume 1. Indianapolis: The Liberty Fund, pp. 262-275.

Tullock, G. (1975). Competing for aid. Public Choice, 21, 41-51. Reprinted in: Rowley, C. K. (Ed.), 2005. The Selected Works of Gordon Tullock, volume 1. Indianapolis: The Liberty Fund, pp. 199-211. 
Tullock, G. (1980). Efficient rent seeking. In Buchanan, J. M., Tollison, R. D. \& Tullock, G. (Eds.), Toward a theory of the rent-seeking society. College Station TX: Texas A\&M Press, pp. 97-112. Reprinted in: Congleton, R. D., Hillman, A. L., \& Konrad, K. A. (Eds.) (2008), 40 Years of research on rent seeking: Theory of rent seeking. Heidelberg: Springer, pp. 105-120.

Tullock, G. (1991). Accidental freedom. In Hillman, A. L. (Ed.), Markets and politicians: Politicized economic choice. Boston and Dordrecht: Kluwer Academic Publishers, pp. 93-112.

Tullock, G. (1993). Rent Seeking. The Shaftesbury Papers. Cheltenham UK: Edward Elgar.

Tullock, G., (1996). The Organization of Inquiry. Durham NC: Duke University Press. Reprinted in: Rowley, C. K. (Ed.), 2005. The Selected Works of Gordon Tullock, volume 3. Indianapolis IL: Liberty Fund, pp. 1-9.

Tullock, G. (2000). People are people. In Tullock, G., Seldon, A. \& Brady, G. L., Whose obedient servant? A primer in Public Choice. London UK: Institute of Economic Affairs, pp. 3-18. Reprinted in: Rowley, C. K. (Ed.), 2005, The Selected Works of Gordon Tullock, volume 4. Indianapolis IN: Liberty Fund, pp, 32-45.

Tullock, G. (2005). The Rent-seeking Society. The Selected Works of Gordon Tullock, volume 5 . Edited by and with an introduction by Charles K. Rowley. Indianapolis IN: Liberty Fund.

Ursprung, H. W. (2002). Where do we go from here? In Winer, S. L. \& Shibata, H. (Eds.), Political economy and public finance - The role of political economy in the theory and practice of public economics. Cheltenham UK: Edward Elgar (in association with the International Institute of Public Finance), pp. 224-231.

Young, W. (2004). Introduction: Professional prejudice and discrimination in the history of economic thought. European Journal of Political Economy, 20, 1-3. 